\title{
ANTIPHOSPHOLIPID ANTIBODIES IN HEALTHY SERBIAN MIDDLE-AGED SUBJECTS: PRELIMINARY DATA
}

\section{ANTIFOSFOLIPIDNA ANTITELA U ZDRAVIH SRPSKIH OSOBA SREDNJIH GODINA: PRELIMINARNI PODACI}

\author{
Mirjana B. Bećarević ${ }^{*}$, Snežana Jovičić2,3, Svetlana D. Ignjatović ${ }^{2,3}$, Duško Mirković2,3 \\ ${ }^{1}$ University of Novi Sad, Faculty of Medicine, Department of Pharmacy, Novi Sad, Serbia \\ ${ }^{2}$ University of Belgrade, Faculty of Pharmacy, Department of Medical Biochemistry, Belgrade, Serbia \\ ${ }^{3}$ Center for Medical Biochemistry, Clinical University Center of Serbia, Belgrade, Serbia
}

\section{Summary}

Background: The investigation of the prevalence of the $\lg G$ and the $\lg M$ isotypes of anticardiolipin $(\mathrm{aCL})$ and anti$\beta 2$ glycoprotein I (aß2gpl) Abs in healthy Serbian middleaged subjects was the main goal of our study. In addition, we analyzed the potential associations of above-mentioned Abs with serum proteins and lipids/lipoproteins.

Methods: Forty healthy subjects were included in our study. Obesity (BMI $30 \mathrm{~kg} / \mathrm{m}^{2}$ ) was present in 8/40 (20\%) subjects. Titers of analyzed Abs were measured by ELISA.

Results: The prevalence of $\operatorname{lgG}$ and $\operatorname{lgM}$ aß2gpl Abs was $5 \%$ and $12.5 \%$, respectively, while the prevalence of $\lg M$ $\mathrm{aCL}$ was $10 \%$. The $\mathrm{lgG}$ a $32 \mathrm{gpl}$ Abs were significantly different between subjects with normal triglycerides levels and those with hypertriglyceridemia (Mann-Whitney, $P=$ 0.014). The significant difference in hsCRP concentrations was observed between subjects with the increased levels of the $\lg M$ isotype of $\mathrm{aCL}$ Abs and those with normal $\lg M \mathrm{aCL}$ values (Mann-Whitney, $P=0.028$ ).

Conclusions: Dyslipidemia and $\mathrm{BMI} \geq 30$ were associated with aPL Abs and therefore, the correction of BMI and lipid status might be beneficial in reduction or elimination of predisposing factors that might trigger thrombotic events in otherwise healthy middle-aged subjects. Larger national study is necessary to confirm our findings.

Keywords: antiphospholipid antibodies, apolipoproteins, complement components, C-reactive protein, haptoglobin, serum amylod $A$

\section{Kratak sadržaj}

Uvod: Analiza prevalentnosti lgG i lgM izotipa antikardiolipinskih ( $\mathrm{aCL}$ ) i anti- $\beta 2$ glikoprotein I (aß2gpl) At kod zdravih sredovečnih stanovnika Srbije je bila glavni cilj naše studije. Dodatno, analizirali smo potencijalnu povezanost gorenavedenih At sa serumskim proteinima i lipidima/lipoproteinima.

Metode: 40 zdravih ispitanika je bilo uključeno u našu studiju. Gojaznost (BMI $\geq 30 \mathrm{~kg} / \mathrm{m}^{2}$ ) je uočena kod $8 / 40$ (20\%) osoba. Titri analiziranih antitela su utvrđivani ELISA testom.

Rezultati: Prevalentnost IgG i IgM aß2gplAt je bila 5\% i $12.5 \%$, redom, dok je prevalentnost $\lg M$ aCL bila $10 \%$. Nivoi lgG aß2gpl At su se značajno razlikovali između ispitanika sa i bez hipertrigliceridemije (Mann-Whitney, $P=$ 0.014). Značajne razlike $u$ hsCRP koncentracijama uočene su između osoba sa povišenim nivoima $\operatorname{lgM} \mathrm{aCL}$ At i onih sa referentim vrednostima (Mann-Whitney, $P=0,028$ ).

Zaključak: Dislipidemija i $\mathrm{BMI} \geq 30$ su bili povezani sa $\mathrm{aPL}$ At uprkos njihovoj niskoj prevalentnosti, i zato korekcija BMI i lipidnog statusa bi bila korisna u redukciji ili eliminaciji predispozirajućih faktora koji mogu da izazovu trombotički događaj kod inače zdravih sredovečnih ispitanika. Obimnije nacionalne studije su neophodne da bi potvrdile naše nalaze.

Ključne reči: antifosfolipidn antitela, apolipoproteini, komplement komponente, C-reaktivni protein, haptoglobin, serum amilod $A$

Address for correspondence:

Professor Mirjana Bećarević, PhD

University of Novi Sad, Faculty of Medicine,

Department of Pharmacy, Novi Sad, Serbia

Hajduk Veljkova 3, 21000 Novi Sad, Serbia

e-mail: bm48mb32@gmail.com and

mirjana.becarevic@mf.uns.ac.rs

ORCID: 0000-0003-2114-8621

List of abbreviations: Abs, antibodies; $a \beta 2 \mathrm{gpl}$, anti- $\beta 2$ glycoprotein I Abs; aCL, anticardiolipin Abs; aPL, antiphospholipid Abs; APS, antiphospholipid syndrome. 


\section{Introduction}

Antiphospholipid antibodies (aPL Abs) represent a diverse group of Abs directed against complexes formed between negatively charged phospholipids (i.e. cardiolipin $(\mathrm{CL})$, phosphatidyl-serine, phosphatidyl-inositol etc.) or blood proteins (i.e. beta 2 glycoprotein I ( $32 \mathrm{gpl})$ ), etc (1-5).

Increased titers of aPL Abs are the main laboratory feature of the antiphospholipid syndrome (APS). It is an autoimmune disease that is (beside the presence of aPL Abs) characterized by the presence of recurrent thrombosis and/or pregnancy losses $(6,7)$. According to the latest classification criteria for the diagnosis of the APS $(8,9)$, the presence of aPL Abs (i.e. the $\lg G$ and/or the $\lg M$ isotype of the anticardiolipin (aCL) and/or the $\lg G$ and/or the lgM isotype of the anti- $\beta 2$ glycoprotein I ( $\beta 2 \mathrm{gpl})$ Abs) must be present at medium to high titers in two or more occasions, at least twelve weeks apart. The reasons why $\beta 2 \mathrm{gpl}$ and $\mathrm{CL}$, as ubiquitously present autoantigens in some persons promotes production of pathogenic autoAbs remains elusive.

There are several studies that investigated the prevalence of aPL Abs in healthy subjects of various nationalities (10-12) and numerous studies that compared levels of aPL Abs in patients with different autoimmune disease vs. healthy subjects (13-16). We have previously reported (13) that in 47 Serbian young (mean \pm SD, $39.68 \pm 13.93,33$ female) lean, healthy adults, levels of aPL Abs were significantly lower in comparison to patients with primary APS and that levels of analyzed serum lipids (cholesterol, HDL-cholesterol, LDL-cholesterol and triglycerides) were below cut-off values in these young subjects. However, no studies that analyze the association of aPL Abs with sera lipids/lipoproteins and proteins in healthy Serbian middle-aged subjects are available. Therefore, the aim of our study was to evaluate the prevalence of aPL Abs in healthy middle-aged Serbian subjects and to investigate the potential correlation between aPL Abs positivity and lipids/lipoproteins (cholesterol, HDL-cholesterol, LDL-cholesterol, triglycerides, apolipoproteins (apo) Al, B and lipoprotein (a) $(L p(a))$ and serum proteins ( $C$-reactive protein (CRP), serum amyloid $A(S A A)$, haptogblobin (HPT), fibrinogen, $\mathrm{C} 3$ and $\mathrm{C} 4$ complement components).

\section{Materials and Methods}

\section{Subjects}

All procedures performed in our study were in accordance with Helsinki declaration (and its later amendments) and with the ethical standards of the institutional ethical committee. Written informed consent was obtained from all individual participants included in the study.
Our study included 40 healthy subjects (mean age $\pm S D, 58.22 \pm 3.47$ ) comprised from our colleagues and our acquaintances that did not show any clinical signs of thrombosis, pregnancy morbidity, infections, cancer and autoimmune diseases. The use of the laboratory information system data for this study was approved by our local Ethical Committee (Ethical Committee of the Clinical University Center of Serbia, Approval No 4815/3). Female to male ratio was $16 / 24$. The body mass index (BMI) was calculated as the weight $(\mathrm{kg}) /$ height $^{2}\left(\mathrm{~m}^{2}\right)$.

\section{Methods}

Serum concentrations of total cholesterol (TC), HDL-cholesterol (HDL-C), LDL-cholesterol (LDL-C), triglycerides (TG) and high sensitivity $\mathrm{C}$-reactive protein (hsCRP) were measured on Olympus AU2700 automated analyzer (Beckman Coulter Inc, USA). Total cholesterol and TG concentrations were determined using standard enzymatic assays. High -density lipoprotein cholesterol concentrations were determined using direct enzymatic method. Friedwald formula was used to calculate LDL-C concentrations, but if TG concentrations $>4.50 \mathrm{mmol} / \mathrm{L}$ direct enzymatic method was used.

Concentrations of hsCRP were measured with an immunoturbidimetric latex assay. Cut-off values for TC, HDL-C, LDL-C, TG and hsCRP were $5.0 \mathrm{mmol} / \mathrm{L}$, $1.55 \mathrm{mmol} / \mathrm{L}, 2.5 \mathrm{mmol} / \mathrm{L}, 1.70 \mathrm{mmol} / \mathrm{L}, 3 \mathrm{mg} / \mathrm{L}$ (for high cardiovascular risk), respectively.

Apolipoprotein A-I, apoB, Lp(a), C3 and C4 complement components $(\mathrm{C} 3, \mathrm{C} 4)$ were determined by immunoturbidimetric procedures on Architect c8000 chemistry system (Abbott Laboratories, Illinois, USA). Reference ranges for apoAl and apoB were: $0.95-1.86 \mathrm{~g} / \mathrm{L}$ (men), 1.01-2.23 g/L (women); 0.49-1.73 g/L (men), 0.53-1.82 g/L (women), respectively. Cut-off value for $L p(a)$ was $300 \mathrm{mg} / \mathrm{L}$. Reference ranges for $\mathrm{C} 3$ and C4 complement components were: $0.82-1.85 \mathrm{~g} / \mathrm{L}$ (men), $0.83-1.93 \mathrm{~g} / \mathrm{L}$ (women); 0.15-0.53 g/L (men), $0.15-0.57 \mathrm{~g} / \mathrm{L}$ (women), respectively (17).

Serum concentration of SAA and HPT were assayed using particle-enhanced immunonephelometry with BN II nephelometer (Siemens Healthcare $\mathrm{GmbH}$, Germany). Cut-off value for SAA was 6.4 $\mathrm{mg} / \mathrm{L}$, while the reference range for HPT was $0.3-2$ $\mathrm{g} / \mathrm{L}$. Fibrinogen concentrations were measured in citrate plasma by prothrombin time (PT)-based method on ACL 7000 analyzer (Instrumentation Laboratory SpA, Milan, Italy). For each analyzer appropriate supplied reagents were used. Reference range for fibrinogen was $1.7-5.4 \mathrm{~g} / \mathrm{L}$.

Antibody levels were estimated by ELISA in patient sera using commercially available reagents of ORGENTEC, Diagnostika GmbH, Germany for the detection of anti- $\beta 2 \mathrm{gpl}$ ( $\mathrm{IgG}$ and $\lg M$ isotypes) and 
anticardiolipin $(\mathrm{aCL})$ ( $\lg \mathrm{G}$ and $\lg M$ isotypes) antibodies. Cut-off values were set in accordance to manufacturer recommendation $(8 \mathrm{U} / \mathrm{mL}$ (for the $\mathrm{lgG}$ and IgM isotypes of aß2gpl Abs), $10 \mathrm{GPL}-\mathrm{U} / \mathrm{mL}$ (for lgG $\mathrm{aCL}$ ) and $7 \mathrm{MPLU} / \mathrm{mL}$ (for lgM aCL Abs).

\section{Statistical analysis}

Shapiro-Wilik test was used to study whether analyzed variables followed a normal distribution. The categoric variables were expressed in percentages (\%), while continuous variables were expressed as mean \pm SD in the case of normal distribution, but if concentrations did not follow a normal distribution pattern, the values were expressed as median (25th 75th percentiles). Mann-Whitney test, Kruskal-Wallis and 2-test were used, when appropriate. The correlation between two quantitative variables was determined with the Spearmanžs correlation test. In all of the above-mentioned tests, $P<0.05$ was considered statistically significant. Analyses were conducted in SPSS 20 (SPSS, Inc, Chicago, IL, USA).

\section{Results}

Obesity (BMI $\geq 30 \mathrm{~kg} / \mathrm{m}^{2}$ ) was present in $2 / 16$ (12.5\%) female subjects and in 6/24 (25\%) male subjects. Increased BMI values (BMI $25-30 \mathrm{~kg} / \mathrm{m}^{2}$ ) were present in eight $(50 \%)$ female and in eight $(33.33 \%)$ male subjects. Our study included 5/16 (31.25\%) female smokers and 6/24 (25\%) male smokers.

Serologic features of analyzed subjects are presented in Table I. Not a single subject had increased titers of the IgG isotype of aCL Abs. Increased levels of the $\lg M$ isotype of $\mathrm{aCL}$ Abs were present in 4 (2 female and 2 male)/40 (10\%) of analyzed subjects. Elevated levels of the $\mathrm{lgG}$ isotype of a $32 \mathrm{gpl}$ Abs were present in only two male subjects (5\%), while increased $\operatorname{lgM}$ a $32 \mathrm{gpl}$ levels were observed in 5 (4 female and 1 male)/40 (12.5\%) of analyzed subjects. Simultaneous presence of the $\lg M$ isotype of both $\mathrm{aCL}$ and $\mathrm{a} \beta 2 \mathrm{gpl}$ Abs was present in three subjects (7.5\%).

The Ig $M$ isotype of $\mathrm{aCL}$ and $\mathrm{a} \beta 2 \mathrm{gpl}$ Abs were in positive correlation $(r=0.882, P=0.000)$ (Figure 1,

Table I Concentrations analyzed parameters in female and male subjects (comparison was done by Mann-Whitney, *P < 0.05).

\begin{tabular}{|c|c|c|c|}
\hline $\begin{array}{c}\text { Parameters } \\
\text { Median (25th-75th) }\end{array}$ & $\begin{array}{l}\text { Female } \\
\mathrm{n}=16\end{array}$ & $\begin{array}{c}\text { Male } \\
\mathrm{n}=24\end{array}$ & $P$ value \\
\hline Age (years, (mean \pm SD)) & $57.19 \pm 3.31$ & $58.92 \pm 3.48$ & 0.130 \\
\hline $\operatorname{BMI}\left(\mathrm{kg} / \mathrm{m}^{2}\right)$ & $26.34(24.33-28.86)$ & $27.44(23.77-30.04)$ & 0.782 \\
\hline Glucose $(\mathrm{mmol} / \mathrm{L})$ & $5.25(5.02-6.02)$ & $5.45(5.20-5.87)$ & 0.589 \\
\hline Cholesterol $(\mathrm{mmol} / \mathrm{L})$ & $6.23(5.80-7.60)$ & $6.15(5.69-6.77)$ & 0.464 \\
\hline Triglycerides $(\mathrm{mmol} / \mathrm{L})$ & $1.63(1.36-2.39)$ & $1.57(1.06-2.61)$ & 0.879 \\
\hline LDL-cholesterol (mmol/L) & $4.23(3.71-4.84)$ & $3.78(3.15-4.30)$ & 0.100 \\
\hline HDL-cholesterol (mmol/L) & $1.30(1.15-1.71)$ & $1.28(1.05-1.48)$ & 0.499 \\
\hline ApoAl $(g / L)$ & $1.58(1.47-1.75)$ & $1.56(1.38-1.77)$ & 0.629 \\
\hline ApoB (g/L) & $1.24(1.09-1.44)$ & $1.25(1.05-1.42)$ & 0.782 \\
\hline Lp(a) $(g / L)$ & $0.17(0.08-0.55)$ & $0.16(0.03-0.32)$ & 0.362 \\
\hline CRP (mg/L) & $2.05(1.29-3.76)$ & $1.54(1.08-3.37)$ & 0.508 \\
\hline SAA (mg/L) & $4.55(2.22-9.05)$ & $3.35(1.45-6.85)$ & 0.334 \\
\hline Fibrinogen $(\mathrm{g} / \mathrm{L})$ & $3.91(2.97-4.50)$ & $4.22(3.8-4.47)$ & 0.163 \\
\hline C3 (g/L) & $1.43(1.30-1.51)$ & $1.51(1.13-1.63)$ & 0.659 \\
\hline $\mathrm{C4}(\mathrm{g} / \mathrm{L})$ & $0.27(0.24-0.32)$ & $0.26(0.21-0.30)$ & 0.415 \\
\hline HPT $(\mathrm{g} / \mathrm{L})$ & $1.39(0.98-1.67)$ & $1.21(0.98-1.72)$ & 0.730 \\
\hline $\mathrm{aCL} \lg \mathrm{G}(\mathrm{GPL} U / \mathrm{mL})$ & $3.29(1.89-4.33)$ & $2.84(1.59-3.55)$ & 0.282 \\
\hline aCLIgM (MPL U/mL)* & $2.76(1.79-5.07)$ & $2.03(1.33-2.78)$ & $0.034 *$ \\
\hline ab2gpl lgG (U/mL) & $2.54(1.77-3.44)$ & $2.16(1.66-2.77)$ & 0.281 \\
\hline ab2gpl IgM (U/mL)* & $3.63(2.19-7.86)$ & $2.19(1.47-3.55)$ & $0.011 *$ \\
\hline
\end{tabular}




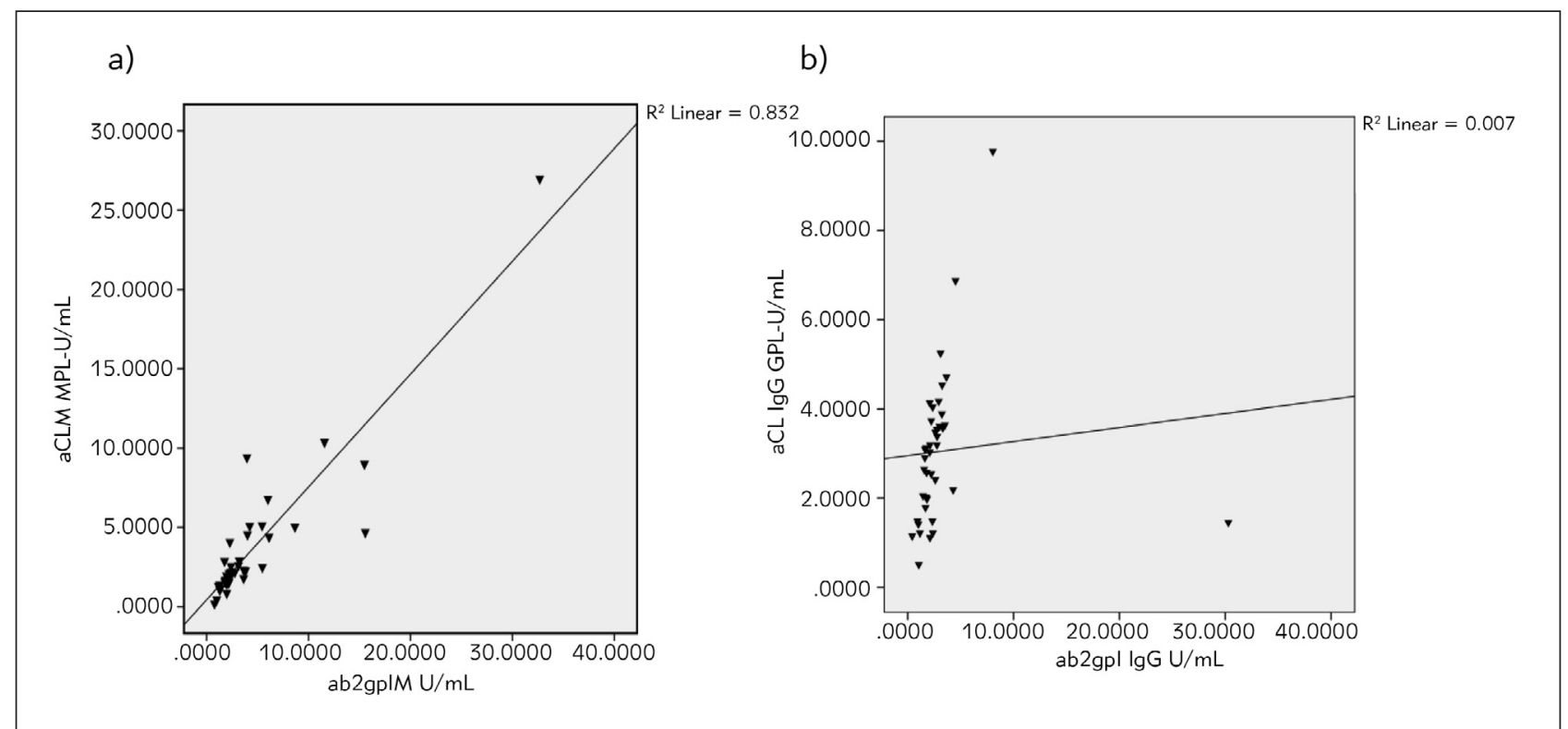

Figure 1 Correlation between the $\lg M(r=0.882, P=0.000$, (Panel (a) and the $\lg G(r=0.632, P=0.000$, (Panel (b) isotypes

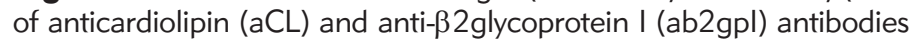

Panel A). The IgM class of aCL Abs and the lgG isotype of a 2 gpl Abs were in positive correlation ( $r=$ $0.319, P=0.045$ ). A positive correlation was found for the $\lg G$ and the $\lg M$ isotype of $\mathrm{aCL}$ Abs $(r=$ $0.502, P=0.001$ ). In addition, the $\lg G$ isotype of $\mathrm{aCL}$ Abs was in positive correlation with both the $\mathrm{lgG}$ $(r=0.632, P=0.000)$ (Figure 1, Panel $B)$ and the $\lg M(r=0.421, P=0.007)$ isotypes of a $\beta 2 \mathrm{gpl}$ antibodies.

The hypertriglyceridemia was noticed in $17 / 40$ $(42.5 \%)$ of analyzed subjects and the concentrations of the $\lg$ isotype of a $32 \mathrm{gpl}$ Abs were significantly different between subjects with and without hypertriglyceridemia (Mann-Whitney, $P=0.014$ ). Subjects with increased $L p(a)$ levels and those with normal $\mathrm{Lp}(\mathrm{a})$ values had significantly different $\mathrm{lgG}$ aß2gpl Abs concentrations (Mann-Whitney, $P=0.026$ ). However, only male subjects showed a positive correlation between $\operatorname{Lpa}(\mathrm{a})$ and the $\lg M$ isotype of a $2 \mathrm{gpl}$ Abs $(r=0.412, P=0.045)$.

Kruskal-Wallis test (One-way ANOVA) revealed that the $\operatorname{lgG}$ isotype of a $\beta 2 \mathrm{gpl}$ Abs $(P=0.020)$, hsCRP $(P=0.048)$, C3c $(P=0.015)$, cholesterol ( $P$ $=0.028)$ and triglycerides $(P=0.012)$ concentrations were significantly different among subjects with different BMI values (obese, increased and normal $\mathrm{BMI})$. The significant difference in body weight values was observed between subgroups of subjects with increased $\lg M$ isotype of a $2 \mathrm{gpl}$ Abs and those without it (i.e. normal IgM a $\beta 2 \mathrm{gpl}$ concentrations, MannWhitney, $P=0.034$ ), while significant difference in hsCRP concentrations was observed between subjects with the increased levels of the $\lg M$ isotype of $\mathrm{aCL}$ Abs and those with normal $\operatorname{lgM}$ aCL values (MannWhitney, $P=0.028$ ).
No correlation between the analyzed Abs and $\mathrm{C} 3 \mathrm{c}$ and $\mathrm{C} 4$ complement components, SAA, CRP, HPT, fibrinogen and apolipoproteins was obtained. However, hsCRP was in positive correlation with SAA $(r=0.511, P=0.001), C 3 c(r=0.469, P=$ $0.002), C 4(r=0.377, P=0.017)$ and HPT $(r=$ $0.388, P=0.013$ ). Fibrinogen concentrations were in positive correlation with triglycerides $(r=0.332, P$ $=0.037)$ and $C 3 c(r=0.479, P=0.002)$.

\section{Discussion}

Mclntyre et al (12) have published that $63 / 775$ (8.1\%) volunteer blood donors (average age: 43 years, range (17-82)) had positive finding of one or more aPL Abs (12). Another study (18) has revealed that $20.7 \%$ of centenarians were positive for $\lg \mathrm{G} \mathrm{aCL}$ and $2.59 \%$ for $\operatorname{lgM}$ aCL Abs, while $54.3 \%$ of centenarians were positive for the $\lg \mathrm{g}$ a $32 \mathrm{gpl}$ and $8.6 \%$ for $\lg M$ a $32 \mathrm{gpl}$ Abs (18). Despite this high aPL Abs prevalence in centenarians (comparable to titers observed in APS patients), the authors of the study did not observe a single vascular event and therefore the authors have suggested that some "unknown protective factor and/or lacking of triggering factors « are responsible for their findings (18). Similarly, Mustonen et al. (19) have reported that single aPL Abs positivity does not seem to carry an elevated risk of thrombosis (in asymptomatic aPL Abs carriers). Avčin et al. (20) reported no statistically significant differences in the frequency of the elevated either $\mathrm{aCL}$ isotype between blood donors (mean age: 34 years, range $(18-65))$ and analyzed children (preschool and adolescent), i.e. 5/52 (9.6\%) blood donors were positive for aCL Abs (5.8\% were positive for $\lg \mathrm{g}$ aCL 
Abs vs. 7/61 (11.4\%) of analyzed children were positive for IgG aCL). The same group (20) have reported no differences in the frequency of the either isotype of $a \beta 2 \mathrm{gpl}$ Abs between blood donors and analyzed children $(4 / 52(7.7 \%)$ of blood donors were positive for a $\beta 2 \mathrm{gpl}$ Abs and 1/52 (1.9\%) were positive for lgG aß2gpl Abs) vs. 4/61 (6.6\%) of analyzed children and (2/61 (3.3\% were positive for IgG aB2gpl Abs)). However, Avčin et al. (20) did not analyze the gender differences in regard with the prevalence of aPL Abs in blood donors and children. Mclntyre et al. (12) have reported that males were positive for aCL more often than females, but no differences in aPL isotypes between gender was observed (12). In addition, the same authors (12) have reported the persistence of the $\lg M a C L$ Abs (in a healthy male repeat blood donor (age: 60 years)) even after 16 months interval between blood draws. Although one might expect the isotype switch from $\lg M$ to $\lg G$ to occur with the loss of the $\lg M$ isotype in the normal antibody response, the authors (12) did not provide an explanation for their observation.

In comparison to above-mentioned studies, our study population was comprised from middle-aged subjects (mean age $\pm S D, 58.22 \pm 3.47$ ) and we observed that not a single subject had increased titers of the $\lg G$ isotype of aCL Abs, but elevated IgM aCL Abs levels were present in $10 \%$ of analyzed persons, while increased titers of the $\lg G$ and $\lg M$ a $\beta 2$ gpl were observed in $5 \%$ and $12.5 \%$ of analyzed subjects, respectively. We have observed that the $\lg M$ isotype was more frequent than the $\lg G$ isotype but this was not statistically significant.

Previously it was reported that $\beta 2 \mathrm{gpl}$ (also known as apolipoprotein (apo) $\mathrm{H}$ ) was implicated in atherogenic and thrombotic processes and that serum $\beta 2 \mathrm{gpl}$ concentrations were elevated in patients with primary hyperlipidaemia (21). In addition, significant correlations were observed between $\beta 2 \mathrm{gpl}$ and triglycerides and total cholesterol concentrations (21). Although in our study we did not measure serum $\beta 2 \mathrm{gpl}$ levels, we observed that $\lg \mathrm{a}$ a $\beta 2 \mathrm{gpl}$ Abs concentrations were significantly different between subjects with and without hypertriglyceridemia. In addition, the concentrations of $\lg \mathrm{g}$ a $32 \mathrm{gpl}$ Abs were significantly different between subjects with increased Lp(a) levels and those with normal levels. Interestingly, only analyzed male subjects showed a positive correlation between the $\lg M$ a $\beta 2 \mathrm{gpl}$ Abs and Lp(a) concentrations.

Previously it was reported that concentrations of $\lg G$ and $\lg M$ aCL Abs were similar in obese and nonobese patients with primary APS (22). In agreement, no differences in regard to either isotype of aCL Abs were observed in our subjects considering their $\mathrm{BMI}$ values. However, in our group, obesity was present in $12.5 \%$ of females and in $25 \%$ of males and we noticed that subjects with different BMI values had significantly different concentrations of the $\lg G$ aß2gpl Abs, hsCRP and C3c. Elevated hsCRP levels and the presence of aPL Abs exhibited some similarities in the pathogenesis of thrombosis (23). It is considered that hsCRP is a predictor of vascular events independently of all other lipids and non-lipid risk factors (23). Lin et al. (24) have reported that in patients with inflammation, $\beta 2 \mathrm{gpl}$ levels were in negative correlation with CRP and in positive correlation with negative acute phase proteins (such as albumin and transferrin). It was reported that acute phase proteins (such as SAA) have been associated with the pathology of anti- $\beta 2 \mathrm{gpl} A b s$ and that SAA levels were increased and correlated with the history of thrombosis in APS patients (25), while in healthy young Japanese, no correlation between CRP and SAA levels was observed (26). In our study, hsCRP concentrations were significantly different between subjects with increased $\operatorname{lgM} \mathrm{aCL}$ Abs titers and those without it. In addition, we observed significant correlation between hsCRP and SAA, HPT and complement components ( $\mathrm{C} 3 \mathrm{C}$ and $\mathrm{C} 4)$. In patients with idiopathic aPL Abs, fibrinogen concentrations correlated with the $\mathrm{aCL} \lg \mathrm{A}$ Abs and the authors (27) suggested that measurement of fibrinogen may be beneficial in defining aPL subjects with higher thrombotic risk that might require pharmacological intervention for lowering fibrinogen levels (27). In our study, fibrinogen concentrations did not correlate with the either isotype of analyzed Abs.

In conclusion, BMI 30 (obesity) and dyslipidemia were associated with aPL Abs despite their low prevalence in analyzed subjects. Antiphospholipid antibodies are regarded as natural autoantibodies and due to "molecular mimicry between microbial epitopes and human $\beta 2 \mathrm{gpl}$ it is possible that in genetically predisposed subjects, generation of aPL Abs might be initiated« (28). However, predisposing factors are not completely elucidated yet and there are several reports that suggest that pro-inflammatory cytokines and acute phase reactants (25) are important for generating "second hit" that is vital in the pathology of aPL Abs. Our study provides a rationale for the fact that correction of $\mathrm{BMI}$ and lipid status might be beneficial in reduction and/or elimination of predisposing factors that might trigger thrombotic events in otherwise healthy Serbian middle-aged subjects. In addition, our results should be regarded with caution (i.e. as preliminary) due to relatively small number of participants included in the study and therefore, larger national study is necessary to confirm our findings.

\section{Acknowledgment}

The authors of the article have no conflict of interest (financial nor non-financial) related to this manuscript. All authors approved the final manuscript as submitted and agree to be accountable for all 
aspects of the work (MB is responsible for analysis, interpretation of data and writing of the Article; SJ and $M B$ were responsible for laboratory measurements of investigated parameters; SJ was responsible for recruitment of subject and providing their data; SI and $D M$ are responsible for the final approval of the Article).

The present work was supported by the Ministry of Science, Education and Technological Develop-

\section{References}

1. Alessandri C, Conti F, Pendolino M, Mancini R, Valesini G. New autoantigens in the antiphospholipid syndrome. Autoimmunity Rev 2011; 10: 609-16.

2. Bećarević $M$. The $\lg G$ and $\lg M$ isotypes of anti-annexin A5 antibodies: relevance for primary antiphospholipid syndrome. J Thromb Thrombolysis 2016; 42: 552-7.

3. Bećarević M. Antibodies against complement components: relevance for the antiphospholipid syndrome-biomarkers of the disease and biopharmaceuticals. Curr Rheumatol Rep 2017; 19: 1 9. DOI 10.1007/s11926017-0669-1.

4. Bećarević M. Detrimental roles of TNF-alpha in the antiphospholipid syndrome and de novo synthesis of antiphospholipid antibodies induced by biopharmaceuticals against TNF-alpha. J Thromb Thrombolysis 2017; 44: 565-70.

5. Bećarević M, Stojanovich Lj, Ignjatović S, Dopsaj V. The lgM Isotype of Anti-Annexin A5 Antibodies and Multiple Positivity of Conventional Antiphospholipid Antibodies: Increasing the Number of Clinical Manifestations of Primary Antiphospholipid Syndrome. Clin Rheum. 2016; 35: 1361-1365, DOI 10.1007/s10067-016-3230-0. issn: 0770-3198.

6. Bertolaccini ML, Amengual $\mathrm{O}$, Andreoli L, et al. 14th International Congress on Antiphospholipid Antibodies Task Force. Report on antiphospholipid syndrome laboratory diagnostics and trends. Autoimmun Rev 2014; 13: 917-30.

7. Bećarević $M$, Mirković $D$, Ignjatović S. Double positivity of the lgG isotype of both anticardiolipin and anti-b2gpl antibodies is associated with the highest number of vascular impairment parameters in patients with primary antiphospholipid syndrome: preliminary data. Clin Rheum 2016: DOI 10.1007/s10067-016-3438-z

8. Miyakis S, Lockshin MD, Atsumi T, et al. International consensus statement on an update of the classification criteria for definite antiphospholipid syndrome. J Thromb Haemost 2006; 4: 295-306.

9. Sciascia S, Radin M, Cecchi I, Levy RA, Erkan D. 16th International congress on antiphospholipid antibodies task force report on clinical manifestations of antiphospholipid syndrome. Lupus 2021; 30(8) 1314-26.

10. Montaruli B, De Luna E, Mengozzi G, et al. Anti-cardiolipin and anti-b2-glycoprotein I antibodies: normal ref- ment of the Republic of Serbia on the basis of contracts No.175036 and No.451-03-68/2020$14 / 200161$.

\section{Conflict of interest statement}

All the authors declare that they have no conflict of interest in this work.

erence ranges in nortwestern Italy. Lupus 2012; 21: 799-801.

11. Martínez-Flores JA, Serrano M, Pérez D, Lora D, PazArtal E, Morales JM, Serrano A. Detection of circulating immune complexes of human IgA and beta 2 glycoprotein I in patients with antiphospholipid syndrome symptomatology. J Immunol Methods 2015; DOI 10.1016 /j.jim.2015.04.002.

12. Mclntyre JA, Wagenknecht DR, Waxman DW. Frequency and specificity of antiphospholipid antibodies (aPL) in volunteer blood donors. Immunobiol 2003; 207: 59-63.

13. Bećarević $M$, Andrejević S, Miljić P, Bonači-Nikolić B, Majkić-Singh N. Serum lipids and anti-oxidized LDL antibodies in primary antiphospholipid syndrome. Clin Exp Rheumatol 2007; 25 (3): 361-6.

14. Bećarević $M$, Čabarkapa $V$, Đerić $M$, Ignjatović $S$. Antiphospholipid antibodies and renal impairment parameters in diabetic nephropathy: preliminary data. Clin Appl Thromb Hemost 2016; DOI 10.1177/ 1076029616642512.

15. Bećarević $M$, Sarić Matutinović $M$, Žarković $M$, Nedeljković Beleslin B, Ćirić J, Ignjatović S. Antiphospholipid Antibodies in Patients with Graves' orbitopathy: Preliminary Data Endocrine 2021; DOI 10.1007/s12020021-02769-z.

16. Ghafar MTA, El-Masry MI. Verification of quantitative analytical methods in medical laboratories. J Med Biochem 2021; 40 (3): 225-36.

17. Bećarević $M$, Ignjatović S. Proinflammatory proteins in female and male patients with primary antiphospholipid syndrome: preliminary data. Clin Rheumatol 2016; 35(10): 2477-83. DOI 10.1007/s10067-016-3345-3.

18. Meroni PL, Mari D, Monti D, Coppola R, Capri M, Salvioli S, Tincani A, Gerli R, Franceschi C. Antibeta 2 glycoprotein I antibodies in centenarians. Experimental Gerontology 2004; 39: 1459-65.

19. Mustonen, $\mathrm{P}$ Lehtonen $\mathrm{KV}$, Javela $\mathrm{K}$, Puurunen $\mathrm{M}$. Persistent antiphospholipid antibody (aPL) in asymptomatic carriers as a risk factor for future thrombotic events: a nationwide prospective study. Lupus 2014; 23: 1468-76.

20. Avčin T, Ambrožič A, Kuhar M, Kveder T, Rozman B. Anticardiolipin and anti-b2glycoprotein I antibodies in 
sera of 61 apparently healthy children at regular preventive visits. Rheumatol 2001; 40: 565-73.

21. Crook MA. Apolipoprotein $\mathrm{H}$ : its relevance to cardiovascular disease. Atherosclerosis 2010; 209: 32-4.

22. Caldas CA, da Mota LMH, de Carvalho JF. Obesity in primary antiphospholipid syndrome is associated with worse outcome. Joint Bone Spine 2011; 78: 319-25.

23. Miesbach W, Gokpinar B, Gilzinger A, Claus D, Scharrer I. Predictive role of hs-C-reactive protein in patients with antiphospholipid syndrome. Immnobiol 2005; 210: 755 -60 .

24. Lin F, Murphy R, White B, et al. Circulating levels of B2gpl in thrombotic disorders and in inflammation. Lupus 2006; 15: 87-93.

25. Artenjak A, Omersel J, Ahlin Grabnar P, et al. Oxidatively altered $\lg G$ with increased immunoreactivity to b2-glyco- protein I and its peptide clusters influence human coronary artery endothelial cells. Lupus 2015; 24: 448-62.

26. Kokubun $M$, Imafuku Y, Okada $M$, et al. Serum amyloid A (SAA) concentrations varies among rheumatoid arthritis patients estimated by SAA/CRP ratio. Clin Chim Acta 2005; 36: 97-102.

27. Ames PRJ, Margarita A, Delgado Alves J, Tommasino C, lannaccone L, Brancaccio V. Anticardiolipin antibody titre and plasma homocysteine level independently predict intima media thickness of carotid arteries in subjects with idiopathic antiphospholipid antibodies. Lupus 2002; 11: 208-14.

28. van den Hoogen LL, van Roon JAG, Radstake TRDJ, Fritsch-Stork RDE, Derksen RHWM. Delineating the deranged immune system in the antiphospholipid syndrome. Autoimmunity Rev 2015; DOI 10.1016/ j.autrev.2015.08.011.

Received: January 10, 2022

Accepted: January 24, 2022 